University of Nebraska - Lincoln

DigitalCommons@University of Nebraska - Lincoln

West Central Research and Extension Center, North Platte

2010

\title{
Estrus Synchronization and Periconceptual Supplementation Affect the Profitability of a Replacement Heifer Enterprise
}

D. M. Larson

University of Nebraska West Central Research and Extension Center, North Platte

R. D. Richardson

Rex Ranch, Ashby, NE

K. H. Ramsay

Rex Ranch, Ashby, NE

R. N. Funston

University of Nebraska West Central Research and Extension Center, North Platte, rfunston2@unl.edu

Follow this and additional works at: https://digitalcommons.unl.edu/westcentresext

Part of the Agriculture Commons

Larson, D. M.; Richardson, R. D.; Ramsay, K. H.; and Funston, R. N., "Estrus Synchronization and Periconceptual Supplementation Affect the Profitability of a Replacement Heifer Enterprise" (2010). West Central Research and Extension Center, North Platte. 31.

https://digitalcommons.unl.edu/westcentresext/31

This Article is brought to you for free and open access by the Agricultural Research Division of IANR at DigitalCommons@University of Nebraska - Lincoln. It has been accepted for inclusion in West Central Research and Extension Center, North Platte by an authorized administrator of DigitalCommons@University of Nebraska Lincoln. 

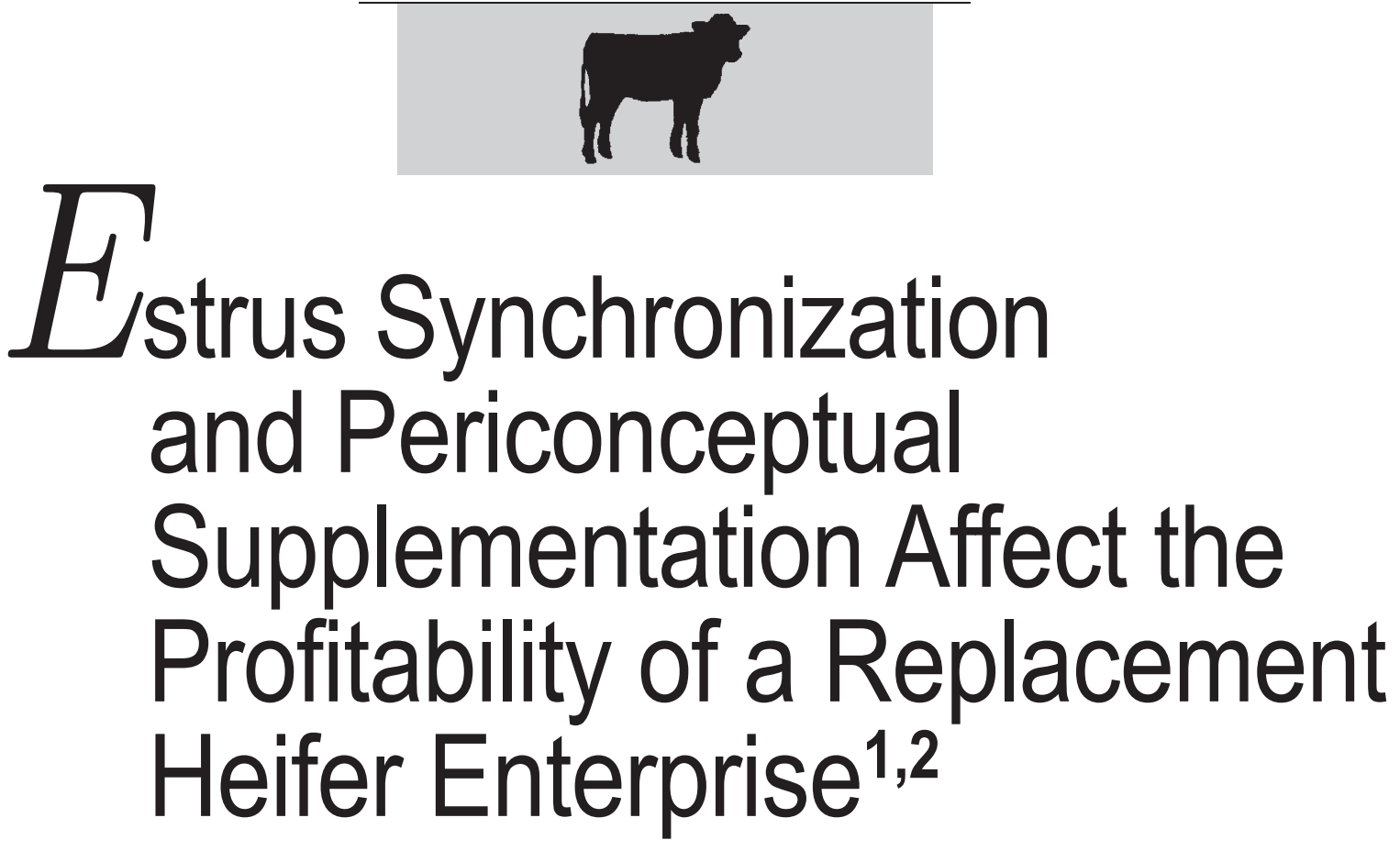

\author{
D. M. Larson, ${ }^{*}$ R. D. Richardson, † K. H. Ramsay, † and R. N. Funston*3 \\ *University of Nebraska West Central Research and Extension Center, North Platte 69101; and \\ †Rex Ranch, Ashby, NE 69333
}

\begin{abstract}
Experiments evaluated estrus synchronization and periconceptual supplementation on pregnancy rate and calf production. Approximately one-half of heifers in 2 pastures (yr 1) or 4 pastures (yr 2) were injected with prostaglandin $F_{2 \alpha}(P G F ; n=1,182)$ or not (NPGF; $n=1,208) 5 d$ after fertile bulls were introduced for 25 d. In yr 2, a total of 1,230 heifers were randomly assigned to 1 of 4 pastures; 2 received a supplement providing $100 \mathrm{~g} / \mathrm{d}$ of Ca propionate $(1.4$ $\mathrm{kg} / \mathrm{d}$, 20\% CP) $2 \mathrm{~d}$ before through $19 \mathrm{~d}$ after bull exposure and 2 did not in a

${ }^{1}$ A contribution of the University of Nebraska-Lincoln Agricultural Research Division (Lincoln), supported in part by funds provided through the Hatch Act. Mention of a trade name, proprietary products, or company name is for presentation clarity and does not imply endorsement by the authors or the University of Nebraska.

${ }^{2}$ The authors wish to acknowledge Kemin Industries (Des Moines, IA) and IVX Animal Health (Saint Joseph, MO) for providing products.

${ }^{3}$ Corresponding author: rfunston2@unl.edu
\end{abstract}

25-d breeding season. Pregnancy rate was reduced $(P<0.01)$ in the $P G F$-synchronized heifers relative to the NPGF heifers (73.7 vs. $78.3 \%$ for PGF and NPGF, respectively. Approximately $10 \%$ more $(P<0.01) P G F$-synchronized heifers that became pregnant calved in the first 21 . Subsequently, weaning weight and the value of steer calves from PGF dams tended to be greater $(P<0.10)$ than those of steer calves from NPGF dams. Supplemented heifers were heavier $(P<$ 0.05) at pregnancy diagnosis; however, pregnancy rate was unaffected $(P>$ 0.10). Calf birth weight was greater $(P<$ 0.05) for calves from dams receiving the Ca propionate supplement, but weaning weight and calf value were similar $(P>0.10)$. In this study, injection of $P G F$ in a 25-d breeding season improved synchrony of calving and increased steer calf weaning weight and value; however, supplemental nutrition during the periconceptual period was of limited value.

Key words: natural service, periconceptual, supplementation, synchronization

\section{INTRODUCTION}

Age at puberty is related to BW, and light heifers reaching puberty at or shortly before the beginning of breeding may not become pregnant until the second estrous cycle during the breeding season and give birth later in the calving season. Estrus synchronization may improve the percentage of pubertal heifers conceiving early in the breeding season. Prostaglandin $\mathrm{F}_{2 \alpha}$ (PGF) injected $96 \mathrm{~h}$ after bull exposure is known to increase the percentage of cows pregnant in the first $9 \mathrm{~d}$ of the breeding season (Whittier et al., 1991). Thus, PGF used in this manner may increase the percentage of pubertal heifers becoming pregnant and subsequently calving earlier.

There is increasing interest in lower cost, low-gain heifer development systems. Recent data (Funston and Deutscher, 2004; Martin et al., 2008) indicate beef heifers reaching less than recommended guidelines of 60 to $66 \%$ of mature BW (Patterson et al., 1992) do not have decreased overall pregnancy rates in a 45-d breeding season. 
However, Martin et al. (2008) did observe a later calving date for heifers developed to 51 versus $57 \%$ of mature $\mathrm{BW}$, indicating a delayed breeding date. Supplementation offered to nutritionally restricted multiparous females before breeding improves embryo survival (Khireddine et al., 1998), but how this type of supplementation may interact with low-gain heifer development is unknown. Low levels of glucose provided to the early embryo may reduce mortality, perhaps by altering the IGF system (Iwata et al., 1998; Jousan and Hansen, 2004). Supplementing cows with a glucogenic precursor, Ca propionate (Nutrocal, Kemin Industries, Des Moines, IA), increased serum glucose concentration and glucose sensitivity (Waterman et al., 2006). Because propionate increases serum glucose, supplementation around breeding may improve early pregnancy rate.

The effects of developing replacement heifers using dormant winter range are not well characterized. Evaluation of a system for developing heifers on native range with targeted supplementation and synchronization to achieve an acceptable pregnancy rate in a short breeding season is needed to improve the sustainability of beef production systems. Therefore, the current studies evaluated the effect of a single PGF injection and periconceptual supplementation in a 25-d breeding season on pregnancy rate and calf production characteristics of heifers developed by grazing winter range.

\section{MATERIALS AND METHODS}

The University of Nebraska-Lincoln Institutional Animal Care and Use Committee approved the procedures and facilities used in these experiments.

\section{Estrus Synchronization}

The 2-yr study used a total of 2,390 heifers. Weaned heifer calves (1,160 heifers, yr 1; 1,230 heifers, yr 2) grazed native Sandhills range at 2 locations in Nebraska from November through May and were provided a supplement $(0.90 \mathrm{~kg} / \mathrm{d}, 30 \% \mathrm{CP}, 120$ $\mathrm{mg} / \mathrm{d}$ of monensin, DM basis, Rumensin, Elanco Animal Health, Indianapolis, IN). The breed composition was approximately 50\% Angus, 25\% Simmental, and $25 \%$ other red breeds. At weaning, heifers received a respiratory complex vaccine (Pyramid 5, Ft. Dodge Animal Health, Overland Park, KS), a Mannheimia (Pasteurella) hemolytica type A1 vaccination (Once $\mathrm{PMH}$, Intervet/Schering-Plough Animal Health, Millsboro, DE), a 7-way clostridial (Ultrabac 7/Somnubac, Pfizer Animal Health, New York, NY), a Brucella abortus vaccination, and moxidectin (Cydectin, Ft. Dodge Animal Health). Approximately 3 mo before breeding, heifers received a respiratory complex booster vaccination (Bovi-Shield Gold FP5, Pfizer Animal Health) and a leptospirosis/ vibriosis vaccination (Vib-Shield plus L5, Novartis Animal Health, Larchwood, IA), and BW was taken (233 \pm $4 \mathrm{~kg}$, yr 1;. $241 \pm 1 \mathrm{~kg}$, yr 2). Heifers grazed early summer Sandhills range and grazed in 1 of 2 pastures in yr 1 and in 1 of 4 pastures in yr 2, with an approximate stocking rate of 1.5 animal unit months/ha during the breeding season, which began on June 15 in yr 1 and on June 13th in yr 2. Heifers were approximately 14 mo of age at the beginning of the breeding season. Approximately one-half the heifers in each pasture were injected with $25 \mathrm{mg}$ of PGF (Prostamate, Agri Laboratories, St. Joseph, MO) 5 d after bulls were introduced, with an average bull:heifer ratio of 1 bull to 28 heifers. Bulls remained with the heifers for an additional $20 \mathrm{~d}$ after PGF injection. The Red Angus cross bulls were mixed ages and had all passed a breeding soundness exam. Pregnancy was diagnosed via transrectal ultrasonography or rectal palpation 45 to $47 \mathrm{~d}$ after bull removal. At this time, nonpregnant heifers were culled. In addition, heifers were culled based on low BW and undesirable confirmation. Pregnant heifers received a leptospirosis/vibriosis vaccination (Vib-Shield plus L5, Novartis Animal Health) at this time.
After pregnancy diagnosis, pregnant heifers grazed native Sandhills range from September to calving and were provided grass hay as needed because of snow cover or adverse weather conditions. From September to January, heifers received $1.3 \mathrm{~kg} / \mathrm{d}$ of supplement (30\% CP, DM basis). From January until calving, heifers received $0.9 \mathrm{~kg} / \mathrm{d}$ of supplement $(25 \%$ CP, DM basis). Before calving, heifers were vaccinated against Clostridium perfringens type $\mathrm{C}$ and Escherichia coli (Bovine Pili Shield + C, Novartis Animal Health) and received lambdacyhalothrin (Saber, Schering-Plough Animal Health). At calving, birth date was recorded and birth weight was estimated with a hoof circumference measuring tape (Calfscale, Nasco, Fort Atkinson, WI) within 12 $\mathrm{h}$ of birth by multiple technicians. Parish et al. (2009) compared this technique for measuring birth weight with visual estimation, a spring scale, and a digital scale and found a correlation of 0.85 with actual birth weight as measured by the digital scale. Dystocia score was also recorded and was defined as $1=$ no assistance, $2=$ easy pull, $3=$ hard pull, $4=$ caesarean section, $5=$ breech, and 6 $=$ dead. During the calving season, heifers were offered free-choice grass and alfalfa hay while grazing native Sandhills range.

In approximately the first week of May, calves were branded and received a 7 -way clostridial vaccine (Ultrabac 7/Somubac, Pfizer Animal Health), and all bull calves were castrated. Dams were provided a supplement during late July and August before weaning $(0.90 \mathrm{~kg} / \mathrm{d}$, 25 to $30 \%$ CP, DM basis) to account for declining CP concentration of late summer Sandhills range. Calves were weaned at approximately $130 \mathrm{~d}$ of age and BW was measured. At weaning, heifer and steer progeny received a respiratory complex vaccine (Pyramid 5, Ft. Dodge Animal Health), a Mannheimia (Pasteurella) hemolytica type A1 vaccination (Once PMH, Intervet/Schering-Plough Animal Health), a 7-way clostridial (Ultrabac 7/Somubac, Pfizer Animal Health), 


\section{Table 1. Composition and calculated nutrient analysis of supplement offered during the periconceptual period in yr 2}

\begin{tabular}{lc} 
Ingredient & DM, \% \\
\hline $\begin{array}{l}\text { Dried distillers grains plus } \\
\quad \text { solubles }\end{array}$ & 30 \\
Wheat middlings & 15 \\
Corn gluten feed & 40 \\
Molasses & 4 \\
Calcium propionate & 8 \\
Pellet binder & 2 \\
Premix package 1 & - \\
Supplement DMI, kg/d & 1.4 \\
Supplement CP, \% & 20 \\
Supplement ME, Mcal/kg & 3.18 \\
\hline
\end{tabular}

${ }^{1}$ Provided $22 \mathrm{klU} / \mathrm{kg}$ of vitamin $\mathrm{A}$ and $240 \mathrm{mg} / \mathrm{d}$ of monensin (Rumensin, Elanco Animal Health, Indianapolis, IN; premix package, Land O'Lakes Purina Feed, Gothenburg, NE).

and moxidectin (Cydectin, Ft. Dodge Animal Health). Booster vaccinations were administered approximately 2 wk later.

\section{Supplementation}

Heifer calves in yr 2 were managed as described in yr 1. Weaned heifer calves grazed native Sandhills range at 2 locations in Nebraska from November through May with supplement. Each ranch unit provided 2 pastures, 1 receiving supplement (GS; Table 1) and 1 not receiving supplement (NS), for a total of 2 GS and 2 NS pastures with a similar stocking rate as in yr 1. Heifers grazed early summer Sandhills range. Supplement was fed for $2 \mathrm{~d}$ before through $19 \mathrm{~d}$ after bull exposure. The bull:heifer ratio was 1:28 in a 25 -d breeding season, at which time heifers at each ranch location were combined into 1 management group. All bulls used in these studies passed a breeding soundness exam before the breeding season. Approximately one-half the heifers in each pasture were injected with $25 \mathrm{mg}$ of PGF $5 \mathrm{~d}$ after bull exposure.

Summer Sandhills range nutrient composition was estimated from mas- ticate samples obtained from 2 esophageally fistulated cows in yr 2. Cows were withheld from feed for $12 \mathrm{~h}$, and then fitted with screen-bottom bags after removal of the esophageal plug. Cows were allowed to graze for approximately $30 \mathrm{~min}$ to obtain samples. Masticate samples were freeze-dried and analyzed for CP (method 990.03; AOAC, 1990), NDF (Van Soest et al., 1991), and ADF (method 973.18; AOAC, 1990). Supplement nutrient composition, including the undegradable intake protein concentration of the feedstuff, was estimated from tabular values (NRC, 2000). Early summer Sandhills range composition was calculated from the samples as described above and contained 9.5\% $\mathrm{CP}, 75.6 \% \mathrm{NDF}$, and $41.0 \% \mathrm{ADF}$.

\section{Statistical Analysis}

Estrus Synchronization. The data for both years were analyzed to identify any year $\times$ treatment interactions. Because none was found $(P>$ 0.05 ), the data for yr 1 and 2 were combined. Further, data were analyzed for the presence of any treatment $\times$ location interactions and none was found $(P>0.05)$. Thus, the data for locations 1 and 2 were combined. The PGF treatment was applied to individual animals; thus, heifer was the experimental unit $(\mathrm{n}=1,208$ and 1,182 for NPGF and PGF, respectively). The effect of supplementation was included in the model where it represented a source of variation $(P$ $\leq 0.15)$. The continuous data were analyzed using the MIXED procedure (SAS Institute Inc., Cary, NC). The binomial data were log-transformed and analyzed using the GLIMMIX procedure (SAS Institute Inc.).

Supplementation. Heifers used in the supplementation experiment were provided supplement in a pasture situation; consequently, the mean for each variable was calculated on a pasture basis. Thus, pasture was the experimental unit ( $\mathrm{n}=2$ per treatment). The effect of PGF synchronization was included in the model where it represented a source of variation $(P$ $\leq 0.15)$. Each variable was tested for location $\times$ treatment interactions. None was found $(P>0.05)$; thus, the combined location data are presented. The continuous data were analyzed using the MIXED procedure (SAS Institute Inc.). The binomial data were log-transformed and analyzed using the GLIMMIX procedure (SAS Institute Inc.).

\section{Economic Analysis}

An economic analysis was conducted using the procedure defined by Feuz (1992). Winter grazing cost for a heifer calf was estimated to be one-half the cost of winter grazing for a mature cow, based on heifer BW at weaning. Hay prices for heifer diets were averaged for the feeding period within each year from Nebraska state average monthly prices (USDAAgricultural Marketing Service, 2007, 2008), and supplement costs were actual prices delivered to the ranch. All nonfeeding costs, including veterinary charges and trucking, were charged at an additional $\$ 0.15 /$ d. Summer grazing cost was estimated to be one-half the cost of summer grazing for a mature cow, based on heifer BW before breeding. The sale value of heifers at weaning and pregnancy diagnosis was calculated from the Nebraska average price reported by USDA-Agricultural Marketing Service (2008) for each individual date. Budgets evaluated the economics from weaning until pregnancy diagnosis and from pregnancy diagnosis until weaning of progeny. The total cost and net return were calculated using the formula developed by Feuz (1992). The total value of all open and culled heifers was subtracted from the total development cost of the entire group of heifers. The total adjusted value of heifer development was then divided by the number of heifers exposed, to arrive at the total cost of a heifer entered into the system. Finally, this value was divided by the pregnancy rate, providing the cost of developing 1 pregnant heifer.

The sale value of progeny at weaning was calculated from the Nebraska average price reported by USDA-Agri- 


\section{Table 2. Effect of prostaglandin $F_{2 \alpha}$ synchronization on growth and pregnancy rates of beef heifers}

\begin{tabular}{|c|c|c|c|c|}
\hline \multirow[b]{2}{*}{ Item } & \multicolumn{2}{|c|}{ Treatment $^{1}$} & \multirow[b]{2}{*}{ SEM } & \multirow[b]{2}{*}{$P$-value } \\
\hline & NPGF & PGF & & \\
\hline $\mathrm{n}$ & 1,208 & 1,182 & & \\
\hline Prebreeding BW, kg & 236 & 239 & 2 & $>0.10$ \\
\hline Pregnancy diagnosis BW, $\mathrm{kg}$ & 352 & 356 & 3 & $>0.10$ \\
\hline Pregnancy diagnosis $\mathrm{BCS}^{2}$ & 5.52 & 5.46 & 0.07 & $<0.05$ \\
\hline Pregnant, \% & 78.3 & 73.7 & & $<0.01$ \\
\hline Culled, $\mathrm{n}$ & 444 & 475 & & \\
\hline Calved in first $21 \mathrm{~d}, \%$ & 77.4 & 87.1 & 2.0 & $<0.01$ \\
\hline Calf sex, $\%$ male & 50.8 & 40.9 & 2.0 & $>0.10$ \\
\hline
\end{tabular}

${ }^{1} \mathrm{NPGF}=$ not injected after bull introduction; PGF = injected with $25 \mathrm{mg}$ of

prostaglandin $\mathrm{F}_{2 \alpha}$ (Prostamate, Agri Laboratories, St. Joseph, MO) $5 \mathrm{~d}$ after bull introduction to synchronize estrus.

${ }^{2}$ Scoring system 1 to $9: 1$ = emaciated; 5 = moderate; 9 = obese.

cultural Marketing Service (2008) for each individual date. A price slide was calculated from historical Nebraska average prices across a range of $\mathrm{BW}$ classes (Darrell Mark, University of Nebraska, Lincoln, personal communication). The cost of winter grazing for a pregnant heifer was estimated to be $65 \%$ the cost of winter grazing for a mature cow, based on heifer BW at pregnancy diagnosis. Hay and supplement costs were computed as described previously. Summer grazing cost was estimated to be $85 \%$ the cost of summer grazing for a mature cow.

The value of a pregnant yearling heifer was added to the cost of developing a heifer until the time she weaned her first calf. The total value of all weaned calves was subtracted from the total development cost of heifers that calved, arriving at the cost of developing 1 cow through weaning of the first calf.

\section{RESULTS AND DISCUSSION}

\section{Estrus Synchronization}

Heifer Reproduction. The effect of estrus synchronization on pregnancy rate and percentage of calving in the first $21 \mathrm{~d}$ is presented in Table 2. Estrus synchronization is an alternative strategy to improve breeding and subsequent calving synchrony.
The basis of the synchronization program used in this study is that the corpus luteum does not respond to PGF for at least $96 \mathrm{~h}$ after ovulation. Whittier et al. (1991) found that PGF administered $96 \mathrm{~h}$ after bull exposure improved calving synchrony of mature cows without affecting overall pregnancy rate. Subsequent data reinforce the system's benefit to calving synchrony in mature, lactating beef cows (Larson et al., 2009). However, few data exist evaluating this system in replacement heifers. In this experiment, prebreeding BW was similar $(P>0.10)$ among heifers, which were randomly assigned to treatment. Synchronization did not affect $(P>0.10)$ BW at pregnancy diagnosis, although BCS was greater $(P<0.05)$ for NPGF heifers. Pregnancy rate was reduced $(P<0.01)$ by $4.6 \%$ in PGF-synchronized heifers relative to NPGF heifers. Potentially, the bull:heifer ratio used may have been insufficient to inseminate the increased number of heifers exhibiting estrus on a single day. Healy et al. (1993) suggested the optimal bull:heifer ratio for estrous-synchronized heifers was approximately 1:25, whereas the current study provided a ratio of 1:28. Although overall pregnancy rate was reduced, more $(P<$ 0.01) heifers injected with PGF that became pregnant calved in the first 21 d. Whittier et al. (1991) found that more cows expressing estrus before the beginning of the breeding season became pregnant within 5 to $9 \mathrm{~d}$ after PGF injection. Recent data (Holm et al., 2008) indicate a greater percentage of heifers synchronized with PGF $6 \mathrm{~d}$ after the beginning of AI that had not exhibited estrus, calve earlier than nonsynchronized heifers. The percentage of male calves was unaffected $(P$ $>0.10)$ by estrus synchronization. Estrus synchronization affected $(P<$ $0.05)$ the offspring differently between sexes; thus, data for steer and heifer calves are presented separately.

Heifer Calf Production. The effect of estrus synchronization on heifer calf production is presented in Table 3. Estrus synchronization with PGF reduced $(P<0.01)$ the heifer calf birth date by $1.6 \mathrm{~d}$, which agrees with the improvement in percentage of dams calving in the first $21 \mathrm{~d}$ of the season. Heifer calf birth weight, dystocia score, weaning weight, and adjusted 205-d BW were similar $(P>$ $0.10)$ between heifer calves from PGF and NPGF dams.

Steer Calf Production. Similar to heifer calves, bull calves were also born $1.7 \mathrm{~d}$ earlier $(P<0.01$; Table $3)$ if the dam received PGF. This is likely related to the increase $(P<$ 0.01 ) in percentage of dams calving in the first $21 \mathrm{~d}$. Bull calves from PGFsynchronized dams were approximately $1 \mathrm{~kg}$ heavier $(P=0.01)$ at birth. Potentially because of the increased birth weight, PGF-synchronized dams of bull calves also experienced more $(P<0.05)$ dystocia. Because the average birth date was earlier for bull calves from PGF-synchronized dams, these calves were also older at weaning. In contrast to heifer calves, bull calves from PGF-synchronized dams were $3.5 \mathrm{~kg}$ heavier $(P<0.05)$ at weaning and tended to have heavier $(P=0.10)$ adjusted 205-d BW. The difference in weaning weight response between bull and heifer calves may result from a combination of the magnitude of differences in birth date and birth weight between treatments.

Economic Analysis. Estrus synchronization using PGF increased 
Table 3. Effect of prostaglandin $F_{2 \alpha}$ synchronization on calf production

\begin{tabular}{|c|c|c|c|c|}
\hline \multirow[b]{2}{*}{ Item } & \multicolumn{2}{|c|}{ Treatment $^{1}$} & \multirow[b]{2}{*}{ SEM } & \multirow[b]{2}{*}{$P$-value } \\
\hline & NPGF & PGF & & \\
\hline \multicolumn{5}{|l|}{ Heifer calves } \\
\hline $\mathrm{n}$ & 376 & 361 & & \\
\hline Birth date, Julian d & 88.7 & 87.1 & 0.4 & $<0.01$ \\
\hline Calf birth weight, $\mathrm{kg}$ & 34.1 & 34.4 & 0.2 & $>0.10$ \\
\hline Dystocia score ${ }^{2}$ & 1.19 & 1.16 & 0.03 & $>0.10$ \\
\hline Weaning weight, kg & 128.3 & 128.6 & 1.1 & $>0.10$ \\
\hline 205-d adjusted weaning weight, $\mathrm{kg}$ & 174.0 & 174.7 & 1.5 & $>0.10$ \\
\hline \multicolumn{5}{|l|}{ Bull calves } \\
\hline $\mathrm{n}$ & 388 & 346 & & \\
\hline Birth date, Julian d & 90.1 & 88.4 & 0.4 & $<0.01$ \\
\hline Calf birth weight, $\mathrm{kg}$ & 38.3 & 39.2 & 0.3 & 0.01 \\
\hline Dystocia score $^{2}$ & 1.31 & 1.42 & 0.04 & $<0.05$ \\
\hline Weaning weight, kg & 131.6 & 135.1 & 1.2 & $<0.05$ \\
\hline 205-d adjusted weaning weight, $\mathrm{kg}$ & 178.3 & 182.2 & 1.7 & 0.10 \\
\hline
\end{tabular}

${ }^{1} \mathrm{NPGF}=$ not injected after bull introduction; PGF $=$ injected with $25 \mathrm{mg}$ of prostaglandin $\mathrm{F}_{2 a}$ (Prostamate, Agri Laboratories, St. Joseph, MO) $5 \mathrm{~d}$ after bull introduction to synchronize estrus.

${ }^{2}$ Dystocia score was defined as $1=$ no assistance, $2=$ easy pull, $3=$ hard pull, $4=$ caesarean section, $5=$ breach, and $6=$ dead. the gross heifer development cost by $\$ 3 /$ heifer over NPGF (Table 4). The value of culled heifers, including those not pregnant and those culled for other reasons, was subtracted from the cost of development. Because of a larger percentage of culled heifers with a greater BW, the net total cost of 1 pregnant yearling heifer was $\$ 13 /$ heifer lower in the PGF-treated group. After adding the cost of maintaining a pregnant heifer through gestation and lactation to the first-year development cost, the gross cost of developing a 2-yr-old cow was still approximately $\$ 13 /$ cow less for the PGF group. Although the value of weaned heifer progeny was not affected $(P>$ $0.10)$ by PGF, steer calves from PGFinjected heifers were more valuable $(P$

\section{Table 4. Effect of prostaglandin $F_{2 \alpha}$ synchronization on heifer economics}

\begin{tabular}{lrrrr} 
& \multicolumn{2}{c}{ Treatment $^{1}$} & & \\
\cline { 2 - 3 } Item & NPGF & PGF & SEM & P-value \\
\hline $\mathrm{n}$ & 1,208 & 1,182 & & \\
Total heifer development cost, \$/heifer & 778 & 781 & & \\
Cull heifer value, \$/heifer & 328 & 363 & & \\
Net cost of developing 1 pregnant heifer, \$/heifer & 711 & 698 & & \\
Cost difference & & -13 & & $>0.10$ \\
Weaned heifer calf value, \$/calf & 375 & 376 & 3 & $<0.10$ \\
Weaned steer calf value, \$/calf & 459 & 466 & 3 & $<$ \\
Net cost of a 2-yr-old heifer, \$/heifer & 619 & 596 & & \\
Cost difference & & -23 & & \\
\hline
\end{tabular}

${ }^{1} \mathrm{NPGF}=$ not injected after bull introduction; PGF = injected with $25 \mathrm{mg}$ of prostaglandin $\mathrm{F}_{2 \alpha}$ (Prostamate, Agri Laboratories, St. Joseph, MO) $5 \mathrm{~d}$ after bull introduction to synchronize estrus.
$<0.10)$ than steers from NPGF heifers. Combining the value of weaned steer and heifer progeny provided a total value of the calves. Subsequently, this value was subtracted from the total cost of development. Estrus synchronization using PGF reduced the net total cost of one 2-yr-old cow by $\$ 23 /$ cow relative to NPGF.

\section{Supplementation}

Heifer Body Weight and Reproduction. Prebreeding BW was greater $(P<0.01$; Table 5$)$ for heifers randomly assigned to GS and continued to have greater BW at pregnancy diagnosis $(P<0.05)$. However, BCS score was similar $(P>0.10)$ between nutritional treatments. Regardless of any differences in BW, pregnancy rate in the current experiment was unaffected $(P>0.10)$ by periconceptual supplemental nutrition. The percentage of pregnant heifers calving in the first $21 \mathrm{~d}$ of the season was also similar $(P>0.10)$ between treatment groups. At pregnancy diagnosis, heifers were approximately $63 \%$ of mature BW. Previous data suggest heifers should reach $65 \%$ of mature BW by the first insemination for a successful breeding season (Patterson et al., 1992). More recent research indicates heifers reaching less than $60 \%$ of their mature BW before breeding have similar pregnancy rates in a 45-d breeding season (Funston and Deutscher, 2004; Martin et al., 2008). Further, final heifer pregnancy rate does appear to be greatly dependent on age at puberty, which is inversely correlated with postweaning growth rate (Lynch et al., 1997; Freetly et al., 2001). Thus, one may not expect final pregnancy rate to be affected by moderately low heifer BW at breeding.

Postweaning ADG can alter age at puberty, reducing the number of estrous cycles before breeding (Lynch et al., 1997; Funston and Deutscher, 2004; Martin et al., 2008). Byerley et al. (1987) demonstrated that the number of estrous cycles a heifer undergoes before breeding is related to pregnancy rate because the first cycle may be less fertile than the third. The 


\section{Table 5. Effect of supplemental periconceptual nutrition on pregnancy and calf production in beef heifers}

\begin{tabular}{|c|c|c|c|c|}
\hline \multirow[b]{2}{*}{ Item } & \multicolumn{2}{|c|}{ Treatment $^{1}$} & \multirow[b]{2}{*}{ SEM } & \multirow[b]{2}{*}{$P$-value } \\
\hline & NS & GS & & \\
\hline $\mathrm{n}$ & 2 & 2 & & \\
\hline Prebreeding BW, kg & 239 & 244 & 1 & $<0.01$ \\
\hline Pregnancy diagnosis BW, $\mathrm{kg}$ & 341 & 347 & 2 & $<0.05$ \\
\hline Pregnancy diagnosis $\mathrm{BCS}^{2}$ & 5.42 & 5.48 & 0.02 & $>0.10$ \\
\hline Pregnant, \% & 72.9 & 69.8 & 2.0 & $>0.10$ \\
\hline Calved in first $21 \mathrm{~d}, \%$ & 79.1 & 82.2 & 2.0 & $>0.10$ \\
\hline Calf birth date, Julian d & 87.9 & 87.0 & 0.5 & $>0.10$ \\
\hline Calf birth weight, kg & 36.1 & 37.0 & 0.2 & $<0.05$ \\
\hline Dystocia score ${ }^{3}$ & 1.33 & 1.26 & 0.04 & $>0.10$ \\
\hline Calf sex, $\%$ male & 48.3 & 46.2 & 4.0 & $>0.10$ \\
\hline Calf weaning weight, $\mathrm{kg}$ & 115.2 & 117.2 & 1.7 & $>0.10$ \\
\hline Calf adjusted 205-d BW, kg & 159.7 & 161.3 & 2.7 & $>0.10$ \\
\hline
\end{tabular}

${ }^{1} \mathrm{NS}=$ not supplemented while grazing early summer Sandhills range; GS = supplemented with $1.4 \mathrm{~kg} / \mathrm{d}$ of a $20 \%$ CP cube providing $100 \mathrm{~g} / \mathrm{d}$ of Ca propionate once daily while grazing early summer Sandhills range.

${ }^{2}$ Scoring system 1 to $9: 1$ = emaciated; 5 = moderate; 9 = obese.

${ }^{3}$ Dystocia score was defined as 1 = no assistance, 2 = easy pull, $3=$ hard pull, $4=$ caesarean section, $5=$ breach, and $6=$ dead. economic ramifications of early pregnancy are underlined by the observation that heifers not conceiving early in the first breeding season have lower lifetime productivity and will continue to calve later (Short and Bellows, 1971; Lesmeister et al., 1973). In a 25-d breeding season, unless a heifer expresses estrus in the first $6 \mathrm{~d}$ of the season, she has only one chance to become pregnant. Increased nutrition around the time of maternal recognition of pregnancy may improve firstservice conception rates (Khireddine et al., 1998).

Fertilization in beef heifers is characteristically high, approximately 80 to $90 \%$, indicating fertilization rate is not a major restriction to the establishment of pregnancy in beef heifers (Henricks et al., 1971; Diskin and Sreenan, 1980; Roche et al., 1981). These studies also reported that embryo survival rate $42 \mathrm{~d}$ after insemination was only $60 \%$. Roche et al. (1981) demonstrated that embryo loss occurs primarily in the first 16 d after breeding. Dunne et al. (2000) also concluded that most embryo loss occurs before d 14, with no marked reduction thereafter. Therefore, improving early pregnancy retention may improve pregnancy success. Khireddine et al. (1998) supplemented concentrate 3 wk before and 3 wk after breeding and improved early pregnancy retention in suckled beef cows. The supplementation scheme used in this experiment was an attempt to improve early pregnancy retention.
However, under the conditions of this study, in which heifers were grazing upland early summer Sandhills range of good quality, they failed to do so.

Calf Production. Calf sex distribution may affect birth date and birth weight. However, the percentage of male calves was similar $(P>0.10)$ among GS and NS dams. There was no calf sex $\times$ treatment interaction $(P>0.05)$; therefore, results reported hereafter for Exp. 1 will combine sexes. Supplementation around breeding did not affect calf birth date $(P$ $>0.10$; Table 5), which agrees with the similar $(P>0.10)$ percentage of heifers calving in the first $21 \mathrm{~d}$ of the season. Calf birth weight was greater $(P<0.05)$ for calves from GS dams. Supplemented dams were heavier prebreeding and at pregnancy diagnosis, and perhaps these heavier dams gave birth to heavier offspring. Regardless of the increase in birth weight, dystocia score was not affected $(P>0.10)$ by GS. Periconceptual supplementation provided no added benefit $(P>$ $0.10)$ to weaning weight of calves. Because there was no difference in birth date, calves from GS and NS dams were of similar age at weaning. Thus, adjusted 205-d BW was also similar $(P>0.10)$ between treatment groups.

Economic Analysis. The net cost to develop a pregnant heifer was approximately $\$ 8 /$ animal less for the GS group (Table 6). This was primar-

\section{Table 6. Effect of supplemental periconceptual nutrition on heifer economics}

\begin{tabular}{lrrrr} 
& \multicolumn{3}{c}{ Treatment $^{1}$} & \\
\cline { 2 - 3 } Item & NS & GS & SEM & $P$-value \\
\hline $\mathrm{n}$ & 2 & 2 & & \\
Total heifer development cost, \$/heifer & 778 & 782 & & \\
Cull heifer value, \$/exposed heifer & 335 & 351 & & \\
Net cost of developing 1 pregnant heifer, \$/heifer & 724 & 716 & & \\
$\quad$ Cost difference & & -8 & & \\
Weaned calf value, \$/calf & 351 & 354 & 5 & $>0.10$ \\
Net cost of a 2-yr-old heifer, \$/heifer & 688 & 694 & & \\
Cost difference & & 6 & & \\
\hline
\end{tabular}

${ }^{1} \mathrm{NS}=$ not supplemented while grazing early summer Sandhills range; GS = supplemented with $1.4 \mathrm{~kg} / \mathrm{d}$ of a $20 \% \mathrm{CP}$ cube providing $100 \mathrm{~g} / \mathrm{d}$ of Ca propionate once daily while grazing early summer Sandhills range. 
ily due to the heavier BW associated with the increased number of culled heifers in the GS group. Weaning weight was similar $(P>0.10$; Table $5)$; thus, the progeny value at weaning was similar $(P>0.10)$ between dams of both nutritional treatments. The gross cost of developing a 2-yrold cow included costs associated with heifer maintenance through gestation and first lactation less the value of a weaned calf, and was $\$ 6 /$ animal greater for the GS group.

\section{IMPLICATIONS}

Estrus synchronization of heifers with the bull:heifer ratios used may reduce pregnancy rate; however, more pregnant heifers gave birth early in the calving season. This results in more valuable steer calves at weaning, reducing the net cost of developing a 2-yr-old cow. Retaining additional heifers beyond replacement needs in a low-input heifer development system and marketing open heifers may provide producers with an additional profit center within their operation. Periconceptual supplementation provided no benefit to time of conception or overall pregnancy rate in this study. However, estrus synchronization of replacement heifers increases the value of progeny, reducing net heifer development cost.

\section{LITERATURE CITED}

AOAC. 1990. Official Methods of Analysis. 15th ed. Assoc. Off. Anal. Chem., Arlington, VA.

Byerley, D. J., R. B. Staigmiller, J. G. Berardinelli, and R. E. Short. 1987. Pregnancy rates of beef heifers bred either on pubertal or third estrus. J. Anim. Sci. 65:645.

Diskin, M. G., and J. M. Sreenan. 1980. Fertilization and embryonic mortality rates in beef heifers after artificial insemination. J. Reprod. Fertil. 59:463.

Dunne, L. D., M. G. Diskin, and J. M. Sreenan. 2000. Embryo and foetal loss in beef heifers between day 14 of gestation and full term. Anim. Reprod. Sci. 58:39.

Feuz, D. M. 1992. Replacement beef heifer economics: When prices and reproductive performance are uncertain. Am. Soc. Farm Manag. Rural Appraisers 56:61.

Freetly, H. C., C. L. Ferrell, and T. G. Jenkins. 2001. Production performance of beef cows raised on three different nutritionally controlled heifer development programs. J. Anim. Sci. 79:819.

Funston, R. N., and G. H. Deutscher. 2004. Comparison of target breeding weight and breeding date for replacement beef heifers and effects on subsequent reproduction and calf performance. J. Anim. Sci. 82:3094.

Healy, V. M., G. W. Boyd, P. H. Gutierrez, R. G. Mortimer, and J. R. Piotrowski. 1993. Investigating optimal bull:heifer ratios required for estrus-synchronized heifers. J. Anim. Sci. 71:291.

Henricks, D. M., D. R. Lamond, J. R. Hill, and J. F. Dickey. 1971. Plasma progesterone concentrations before mating and in early pregnancy in the beef heifer. J. Anim. Sci. 33:450.

Holm, D. E., P. N. Thompson, and P. C. Irons. 2008. The economic effect of an estrus synchronization protocol using prostaglandin in beef heifers. Theriogenology 70:1507.

Iwata, H., S. Akamatsu, N. Minami, and M. Yamada. 1998. Effects of antioxidants on the development of bovine IVM/IVF embryos in various concentrations of glucose. Theriogenology 50:365.

Jousan, F. D., and P. J. Hansen. 2004. Insulin-like growth factor-I as a survival factor for the bovine preimplantation embryo exposed to heat shock. Biol. Reprod. 71:1665.

Khireddine, B., B. Grimard, A. A. Ponter, C. Ponsart, H. Boudjenah, J. P. Mialot, D. Sauvant, and P. Humblot. 1998. Influence of flushing on LH secretion, follicular growth and the response to estrus synchronization treatment in suckled beef cows. Theriogenology 49:1409.

Larson, D. M., J. A. Musgrave, and R. N. Funston. 2009. Effect of estrus synchronization with a single injection of prostaglandin during natural service mating. Nebr. Beef Rep. MP 92:13.

Lesmeister, J. L., P. J. Burfening, and R. L. Blackwell. 1973. Date of first calving in beef cows and subsequent calf production. J. Anim. Sci. 36:1.

Lynch, J. M., G. C. Lamb, B. L. Miller, R. T. Brandt Jr., R. C. Cochran, and J. E. Minton.
1997. Influence of timing of gain on growth and reproductive performance of beef replacement heifers. J. Anim. Sci. 75:1715.

Martin, J. L., K. W. Creighton, J. A. Musgrave, T. J. Klopfenstein, R. T. Clark, D. C Adams, and R. N. Funston. 2008. Effect of prebreeding body weight or progestin exposure before breeding on beef heifer performance through the second breeding season. J. Anim. Sci. 86:451.

NRC. 2000. Nutrient Requirements of Beef Cattle. 7th ed. Natl. Acad. Press, Washington, DC.

Parish, J. A., T. Smith, J. R. Parish, T. F. Best, and H. T. Boland. 2009. Evaluation of four different methods of calf birth weight data collection. Prof. Anim. Sci. 25:716.

Patterson, D. J., R. C. Perry, G. H. Kiracofe, R. A. Bellows, R. B. Staigmiller, and L. R. Corah. 1992. Management considerations in heifer development and puberty. J. Anim. Sci. 70:4018.

Roche, J. F., M. P. Boland, and T. A. McGeady. 1981. Reproductive wastage following artificial insemination in cattle. Vet. Rec. 109:95.

Short, R. E., and R. A. Bellows. 1971. Relationships among weight gains, age at puberty and reproductive performance in heifers . J. Anim. Sci. 32:127.

USDA-Agricultural Marketing Service. 2007-2008. NE-IA weekly hay review. http:// www.ams.usda.gov/AMSv1.0/ams.fetchTemplateData.do?startIndex $=1 \&$ template $=$ Tem plateW\&page $=$ SearchHayReports Accessed March 7, 2010.

USDA-Agricultural Marketing Service. 2008. Nebraska weekly feeder cattle auction summary. http://www.ams.usda.gov/mnreports/ wh_ls795.txt Accessed July 22, 2008.

Van Soest, P. J., J. B. Robertson, and B. A. Lewis. 1991. Methods for dietary fiber, neutral detergent fiber, and nonstarch polysaccharides in relation to animal nutrition. J. Dairy Sci. 74:3583.

Waterman, R. C., J. E. Sawyer, C. P. Mathis, D. E. Hawkins, G. B. Donart, and M. K. Petersen. 2006. Effects of supplements that contain increasing amounts of metabolizable protein with or without Ca-propionate salt on postpartum interval and nutrient partitioning in young beef cows . J. Anim. Sci. 84:433.

Whittier, J. C., R. W. Caldwell, R. V. Anthony, M. F. Smith, and R. E. Morrow. 1991. Effect of a prostaglandin $\mathrm{F}_{2 \alpha}$ injection 96 hours after introduction of intact bulls on estrus and calving distribution of beef cows. J. Anim. Sci. 69:4670. 